\title{
PEMETAAN JENIS DAN RUANG LINGKUP PENCARIAN INFORMASI PEKERJAAN PENDUDUK MISKIN PEDESAAN
}

\author{
Pawit M. Yusup ${ }^{1}$ Priyo Subekti ${ }^{2}$, Rohanda ${ }^{3}$ \\ 1,2,3 Program Studi Ilmu Perpustakaan Universitas Padjadjaran \\ 1 pawit.m.yusup@unpad.ac.id ${ }^{2}$ priyo.subekti@gmail.com³r rohanda@yahoo.com
}

\begin{abstract}
Research on the subject of rural poor has always had a strategic value in the constellation of Indonesia human development, especially development oriented poverty reduction efforts. This research aims to study further aspects of rural poor experience related to their work, especially in terms of information behavior. The research method used was qualitative, with data collection through observation and depth interviews with 22 informants categorized as poor in the rural southern part of West Java. The research result shows that: (1) the involvement of the information seeking and used in connection with the work of the rural poor, are generally embedded and embodied in the form of odd jobs; (2) the scope of the types and sources of information seeking and used by rural poor people, is very limited, namely about the neighbors, close relatives, and others similar work.
\end{abstract}

Keywords: Poverty, rural, ood jobs, information seeking.

ABSTRAK - Penelitian dengan subjek penduduk miskin pedesaan selalu memiliki nilai strategis dalam konstelasi pembangunan manusia Indonesia seutuhnya, utamanya pembangunan yang berorientasi pada upaya pengurangan angka kemiskinan. Penelitian ini bertujuan untuk mengkaji lebih jauh mengenai aspek pengalaman penduduk miskin pedesaan terkait pekerjaan mereka, terutama dilihat dari sisi perilaku informasi. Metode penelitian yang digunakan adalah kualitatif, dengan teknik pengumpulan data melalui observasi dan wawancara mendalam terhadap 22 orang informan berkategori miskin di pedesaan Jawa Barat Bagian Selatan. Hasil penelitian menggambarkan bahwa: (1) keterlibatan informasi yang dicari dan digunakan terkait pekerjaan orang miskin di pedesaan, umumnya melekat dan mewujud dalam bentuk pekerjaan serabutan; (2) ruang lingkup dari jenis dan sumber-sumber informasi yang dicari dan digunakan oleh orang miskin pedesaan, amat terbatas, yakni seputar tetangga, kerabat dekat, dan sesama pekerjaan sejenis.

Kata Kunci: Kemiskinan, pedesaan, pekerjaan serabutan, pencarian informasi.

\section{PENDAHULUAN}

Kajian mengenai orang miskin atau penduduk miskin dari sudut pandang mana pun tetap memiliki nilai strategis dalam proses pembangunan manusia Indonesia secara keseluruhan, setidaknya bagi kalangan ilmuwan, peneliti, dan para pengambil kebijakan. Hasil kajiannya pun memiliki manfaat yang jelas dalam konstelasi pembangunan di semua lini, mulai dari lini yang paling atas yakni kelompok masyarakat elit dan mapan secara ekonomi, sampai pada lini yang paling bawah, yakni kelompok masyarakat yang secara sosial ekonomi berada pada posisi "tidak memiliki apa-apa" (Yusup, 2013). Dalam beberapa kepustakaan digital, kelompok masyarakat pada posisi ini dikenal dengan nama orang pinggiran. Tulisan ini lebih banyak menggunakan istilah orang miskin, penduduk miskin, warga miskin, keluarga miskin, atau masyarakat miskin, untuk merujuk kepada mereka yang dalam kehidupan sosialnya berada dalam posisi "pinggiran".

Dalam kehidupan sosialnya, penduduk miskin hidup berbaur dengan penduduk lainnya 
yang secara sosioekonomi tidak termasuk kategori miskin. Yang membedakannya hanyalah pada aspek-aspek kepemilikan harta benda atau properti lain yang secara fisik dan sosial menggambarkan kedudukan pada stratifikasi yang berbeda. Dilihat dari segi batasan saja, misalnya, konsep miskin itu bervariasi, terutama jika dilihat dari sudut pandang etik dan emik. Miskin bisa jadi bermakna tidak memiliki apa-apa dalam hampir segalanya. Miskin juga bisa dimaknai sebagai orang yang ditakdirkan belum berhasil dalam berusaha mencari penghidupan.

Gambaran realitas kemiskinan di atas, utamanya untuk menegaskan kembali bahwa terdapat banyak sekali penduduk miskin yang tersebar di hampir semua wilayah, termasuk di pedesaan. Penelitian ini mengambil lokasi di Jawa Barat bagian Selatan, terutama Kabupaten Ciamis. Dipilih lokasi ini dengan alasan bahwa menurut informasi yang dikemukakan oleh BPS (Badan Pusat Statistik), kesenjangan antara penduduk kaya dan miskin di Jawa Barat termasuk tertinggi di Indonesia.

Tema penelitian ini sesuai dengan program NAWACITA-nya Presiden Joko Widodo dan Jusup Kalla yang dilontarkan ketika mereka mencalonkan diri sebagai Presiden RI, khususnya pada butir ke-3, yakni membangun Indonesia dari pinggiran dengan memperkuat daerah-daerah dan desa dalam kerangka negara kesatuan.

Secara spesifik, penelitian ini lebih dititikberatkan pada kajian mengenai pemetaan masalah miskin dan kemiskinan pedesaan di wilayah ini, terutama dilihat dari aspek variasi jenis informasi penghidupan yang menjadi pencaharian pokoknya, aspek variasi jenis informasi pekerjaan yang dicari dan digunakan mereka sebagai basis survivabilitas kehidupannya. Intinya, bagaimana orang-orang miskin menginterpretasikan harapan-harapan akan pengalaman berpenghidupan (livelihood) selama ini; dan jenis pekerjaan seperti apa yang mereka jalani selama ini.

Agar tema penelitian lebih terarah dan mencakupi banyak aspek terkait dengan variasi jenis pekerjaan yang dilakukan orang miskin di pedesaan, maka rumusan masalahnya ditetapkan pada aspek "Bagaimana memetakan variasi jenis pekerjaan yang dicari dan digunakan orang miskin pedesaan selama ini sebagai basis survivabilitasnya". Sedangkan tujuannya adalah untuk mengkaji secara lebih spesifik aspek variasi jenis pekerjaan yang dicari dan digunakan orang miskin pedesaan selama ini, sehingga bisa dipetakan dengan lebih jelas.

\section{TINJAUAN PUSTAKA}

Miskin bisa diartikan artinya mereka sudah berjuang dan berusaha namun belum berhasil. Tegasnya, konsepsi miskin dan kemiskinan bersifat kontekstual (Yusup, Komariah \& Rohanda, Mengungkap Pengalaman Keluarga Miskin Pedesaan di Jawa Barat dalam Menggunakan Informasi dan Sumber-Sumber Informasi Kesehatan, 2015).

Dalam kajian yang lebih bersifat etik dan terukur, termasuk batasan yang dikembangkan oleh BPS dan Bank Dunia, secara spesifik, sedikitnya ada 8 (delapan) dimensi non-ekonomi pendu- duk miskin, yakni: (1) ketidakmampuan memenuhi kebutuhan dasar seperti sandang, 
pangan dan perumahan; (2) aksesibilitas ekonomi rendah terhadap pendidikan, kesehatan, sanitasi, dll.; (3) kemampuan akumulasi kapital dan investasi yang rendah; (4) rentan ter- hadap goncangan faktor eksternal seperti teknis, alam, ekonomi, sosial, politik); (5) kualitas sumberdaya manusia dan penguasaan sumberdaya alam rendah; (6) terbatasnya keterlibatan dalam kegiatan sosial kemasyarakatan; (7) terbatasnya akses terhadap kesempatan kerja secara berkelanjutan; dan (8) ketidakmampuan berusaha karena cacat fisik dan atau mental (Rusastra \& Napitupulu, 2010).

Penduduk miskin hidup tersebar di hampir semua wilayah, baik di kota maupun di desa, bahkan menurut laporan Bank Dunia, sebagian besar penduduk berkategori miskin itu tinggal di pedesaan dengan kondisi yang memprihatinkan. Data dari Bank Dunia (Bank Dunia, 2006) melaporkan bahwa sebagian besar penduduk miskin tinggal di pedesaan (69\%), bekerja di sektor pertanian (64\%), sifat pekerjaan adalah informal (75\%), dan sekitar $22 \%$ adalah sebagai pekerja keluarga yang tidak dibayar. Sementara itu, pada dimensi non-ekonomi, konsep kemiskinan terkait dengan kapasitas sumberdaya manusia, aksesibilitas terhadap kebutuhan utama, dan keterlibatan pada kesempatan kerja dan berusaha dalam arti luas, termasuk keterbatasan dalam mengakses dan menemukan informasi mengenai apapun yang bisa dijadikan "pintu" menuju kegiatan usaha untuk memberdayakan diri dan keluarga.

\section{METODE PENELITIAN}

Metode yang digunakan dalam penelitian ini adalah kualitatif interpretif, yang secara khusus digunakan untuk menjelaskan konsep miskin menurut sudut pandang orang miskin serta pengalaman-pengalaman mereka dalam mencari informasi pekerjaan selama ini. Peneliti melakukan observasi secara langsung, sambil melakukan wawancara secara mendalam terhadap informan kunci. Peneliti mencatat segala aktivitas informan, melakukan wawancara tidak berstruktur, dan terkadang pada kondisi tertentu ikut ambil bagian dengan kehidupan dan pekerjaan mereka (observatory participation).

\section{HASIL DAN PEMBAHASAN}

Dalam kegiatan ini, peneliti melakukan kategorisasi berdasarkan hasil observasi dan wawancara di lapangan, terutama kategorisasi berdasarkan jenis pekerjaan yang dilakukan oleh informan dan para penduduk miskin di pedesaan. Hasil dari kategorisasi penelitian ini kemudian disusun, dipetakan, dan disederhanakan dengan cara memvisualisasikannya dalam bentuk model visual atau model tabulasi data.

Dengan menggunakan pendekatan observasi langsung ke lapangan ini, peneliti berhasil mengeksplor jenis-jenis pekerjaan yang dilakukan oleh orang miskin pedesaan. Bagaimana mereka menjalani proses kehidupan dengan beragam jenis pekerjaan yang dicari dan dijalankannya selama ini, yang pada tahap prasurvei dan pada hasil penelitian sebelumnya, sudah ditemukan tidak kurang dari 55 jenis pekerjaan yang dijalani oleh penduduk miskin pedesaan. Mereka hidup dengan jenis pekerjaan 
yang pada umumnya bersifat serabutan, namun mereka bisa bertahan hidup, meskipun penghasilannya tidak mencukupi untuk memenuhi kebutuhan pokok sekalipun (Yusup, Silvana, \& Subekti, Memetakan Lingkup Informasi Penghidupan Orang Miskin Pedesaan, 2013).

Jenis-jenis pekerjaan seperti dimaksudkan dalam paragraf di atas, masing-masing berbeda satu sama lain. Artinya, masing-masing dari pekerjaan atau bentuk pekerjaan dimaksud bersifat unik. Meskipun secara "ekonomi” hampir seluruh jenis pekerjaan yang dijalani oleh penduduk miskin pedesaan tidak pernah mencukupi untuk membiayai kebutuhan-kebutuhan dasar keluarga mereka, namun pekerjaan tersebut tetap menjadi tumpuan kehidupannya. Beberapa contoh jenis pekerjaan dimaksud antara lain adalah: pencari kayu bakar di hutan terdekat, pencari daun pisang untuk dijual di pasar-pasar tradisional, pencari dan penggali bonggol-bonggol kayu untuk dijadikan kayu bakar dan dijual ke tetangga, pencari ikan di kali dan dari rawa-rawa terdekat, pedagang jajanan anak yang dijajakan secara keliling dengan digendong, pencari sayuran yang tumbuh liar di sawah, pencari keroto untuk pakan burung, dan jenis pekerjaan lain yang bersifat khas. Jenis-jenis pekerjaan ini nantinya dijelaskan dan dikaji satu per satu untuk kemudian dikategorisasikan dan dicari kesamaan atau perbedaan khasnya sehingga bisa dipetakan secara jelas. Hasil pemetaan ini kemudian divisualisasikan dalam bentuk model tabulasi jenis pekerjaan atau penghidupan penduduk miskin pedesaan. Model pemetaan ini nantinya bisa dikembangkan lagi menjadi modelmodel penghidupan orang miskin pedesaan yang dikaitkan dengan aspek tertentu secara lebih spesifik, misalnya aspek kebutuhan informasi, aspek kebutuhan dasar, aspek kebutuhah meningkatkan kemampuan ekonomi keluarga, aspek ketinggalan informasi, aspek komunikasi sosial, aspek lingkup usaha, dan dan aspek-aspek lainnya yang ditemukan di lapangan.

Sumber data penelitian diperoleh melalui hasil pengamatan langsung dan wawancara dengan informan yang jumlahnya 22 orang, yang termasuk penduduk berkategori miskin, sesuai dengan kriteria dari Bank Dunia dan BPS sebagaimana sudah dikemukakan di bagian lalu. Banyaknya informan ini didasarkan atas pertimbangan kecukupan sesuai dengan kriteria sampling purposif (Cresswell, 2008). Seluruh informan ini memiliki pekerjaan pokok sebagai buruh dan bekerja secara serabutan di sektor pertanian tradisional. Mereka tidak ada yang hanya menekuni satu jenis pekerjaan. (Lihat tabulasi jenis pekerjaan (Tabel. 1) pada pembahasan selanjutnya.

Hasil observasi dan wawancara di lapangan menggambarkan banyak sekali jenis pekerjaan yang dilakukan oleh orang berkategori miskin di pedesaan. Sedikitnya ada 55 jenis pekerjaan yang berhasil peneliti catat dan kaji. Informasi mengenai jenis pekerjaan ini berasal dari keterangan informan dan hasil observasi langsung peneliti selama kurun waktu tahun 2013-2015. Berikut adalah jenis pekerjaan dimaksud:

\section{Pencari kayu bakar di hutan terdekat:} Pada musim "kosong pekerjaan”, yakni di waktu habis matun kedua dan masa menunggu musim panen padi tiba, biasanya ada waktu sekitar 1-2 
bulan. Pada waktu itu sejumlah orang miskin bekerja sebagai pencari kayu bakar di hutan terdekat. Mereka memotong dan mengambil ranting-ranting pohon yang kering yang jatuh ke tanah, lalu mengumpulkannya untuk kemudian dijual guna mendapatkan sejumlah uang.

2. Pencari ikan di kali, rawa-rawa, dan sawah rancah: Di antara orang miskin di pedesaan, ada sejumlah orang yang pekerjaannya mencari ikan yang ada di kali, rawa-rawa dan rancah terdekat, baik dengan cara dipancing, dijala, dijaring, atau distroom dengan listrik, atau bahkan ada yang menggunakan bahan peledak dan racun (potasium, me- reka menyebutnya portas, mencari ikan dengan cara diportas) untuk melumpuhkan ikan tadi. Ikan hasil buruannya tadi dijual ke tetangga atau ke pasar.

\section{Pencari daun pisang: Mereka} mengumpulkan lembaran-lembaran daun pisang yang masih bagus untuk dijual ke pasar guna men- dapatkan uang untuk sekadar menyambung hidup. Biasanya jenis pekerjaan ini dilakukan oleh kaum perempuan, terutama ibu rumah tangga, atau janda.

4. Pemulung: Mereka mencari barangbarang buangan, atau barang-barang yang sudah dibuang oleh pemiliknya, yang pada umumnya berupa sampah plastik, kardus bekas, botol bekas, dan barang-barang bekas lain yang "katanya" bisa didaur ulang oleh penampungnya.

5. Pencari kayu bakar dari "bonggol" kayu yang habis ditebang: Jenis pekerjaan ini hanya bisa dilakukan oleh laki-laki yang masih kuat tenaganya. Mereka menggali akar-akar kayu besar yang habis ditebang, untuk kemudian dibelah kecil-kecil sehingga bisa dijadikan kayu bakar, dan dijual ke tetangganya.

\section{Pedagang mainan anak-anak keliling:}

Beragam jenis dan ukuran mainan anak-anak dijajakan oleh mereka. Adapun jenis mainannya pada umumnya terbuat dari plastik, seperti misalnya $h p$-hp-an (handphone mainan), mobilmobilan (mobil mainan), sepeda motor mainan, gangsing/panggal, dsb. Selain itu, ada juga jenis mainan anak yang terbuat dari kayu, kertas, bambu, dll. Harganya pun beragam, namun pada umumnya di bawah Rp10.000 per buah, bahkan ada sejenis mainan anak yang harganya hanya lima ratus rupiah per buahnya. Anak-anak dari orang miskin banyak yang membeli jenis mainan yang murah ini.

\section{Pedagang jajanan anak keliling:}

Pedagang jenis ini tiap hari berkeliling kampung, menjajakan dagangannya yang berupa beberapa jenis jajanan anak-anak seperti gulali, es lilin, kembang gula, kem- bang kapas, kerupuk pedas, dan lainnya yang bisa dimakan secara langsung oleh anak-anak. Cara membawanya ada yang dengan roda dorong, dipikul, dijinjing, dipanggul, atau pakai sepeda ontel. Mereka sering mendatangi kerumunan anak- anak yang sedang bermain.

\section{Pedagang jajanan anak di kawasan} sekolah: Ini mirip seperti pedagang jajanan anak yang disebutkan di atas, namun jenis pedagang ini hampir selalu "mangkal" di kawasan sekolah. Mereka berjualan sepanjang waktu sekolah buka, yakni sekitar pukul 07.00 hingga bubar sekolah, atau jika dagangannya habis, mereka lebih cepat pulang. 
9. Pedagang jajanan anak musiman: Prinsipnya sama dengan jenis pedagang jajanan anak sebagaimana dijelaskan di atas, namun sang pedagang ini hanya sambilan saja berdagang jajanan anak. Mereka pada umumnya memiliki jenis pekerjaan yang lebih "tetap" seperti misalnya sebagai buruh tani. Seperti sudah dikemukakan di atas, bahwa bertani itu sifatnya musiman, jadi punya waktu "nganggur", maka untuk mengisi kekosongan pe- kerjaan ini, mereka berdagang jajanan anak. Jenis pedagang seperti ini biasanya hanya berdagang pada saat-saat tertentu dan pada saat ada keramaian di kampungnya, seperti misalnya di acara hajatan keluarga, di acara kegiatan "muludan" (peringatan hari maulid Nabi SAW), di acara "rajaban" (peringatan hari Isra" Mi”raj Nabi SAW), acara imtihan (acara kenaikan kelas di sekolah keagamaan atau madrasah), acara nariyahan (sholawat bersama), acara yasinan (membaca surat yaasin secara bersama), dan di acara sejenis lainnya yang sering diadakan di pedesaan.

10. Pedagang bakso keliling: Yakni sejenis pedagang yang sudah sama-sama kita kenal. Mereka ada yang menggunakan roda dorong atau dipikul. Mereka menjajakan dagangan baksonya keliling kam- pung.

\section{Pedagang sayuran matang keliling:} Kalau di kota pada umumnya sayuran matang dijual di warung nasi, rumah makan, ataupun restoran, maka di kampung tempat penelitian ini berlangsung, ada sejumlah orang, biasanya kaum ibu, yang menjajakan sayuran yang siap makan (matang) ke rumah-rumah. Di kampung, hampir tidak ada rumah makan atau warung nasi yang sifatnya "tetap".
12. Pedagang sayuran keliling (peda- gang gowengan): Pedagang jenis ini dilakukan oleh laki-laki maupun perempuan di pedesaan. Mereka membawa beragam jenis sayuran mentah untuk bahan lauk-pauk, baik yang berasal dari kelompok nabati maupun dari jenis ikan dan ada kalanya ayam sayur. Mereka menjajakan dagangannya ke rumah- rumah penduduk.

\section{Pencari sayuran yang tumbuh liar di} sawah: Jenis usaha ini sering dilakukan oleh kaum perempuan, namun kaum laki-laki juga ada yang melakukannya hanya dalam bentuk sambilan sehabis bekerja di sawah seharian, sebelum pulang mereka mencari sayuran yang tumbuh di sawah untuk dibawa pulang. Sedangkan kaum perempuan biasanya memang sengaja mencari sayuran seperti genjer (mereka menyebutnya gendot), eceng, krema, bayam liar, dan lainnya untuk kemudian dijual ke pasar atau tetangganya.

14. Penderes nira kelapa: Di lokasi penelitian, jenis usaha seperti ini disebut dengan tukang deres. Caranya dengan memotong batang tandan kelapa yang masih muda kemudian diambil cairannya (disebut legen atau nira) yang berasa manis jika diminum. Gunanya untuk membuat gula kelapa setelah melalui proses pengolahan yang melelahkan. Biasanya, pekerjaan sebagai penderes ini juga sekaligus sebagai pembuat gula kelapa (gula merah).

15. Pedagang bubur keliling: Ada beberapa jenis bubur, seperti bubur ayam, bubur kacang ijo (kacang hijau), bubur beras merah, bubur sumsum (bubur halus), bubur lemu, bubur ayam, dll. Pada umumnya, pedagang bubur ini bertindak sebagai 
pembuat dan sekaligus penjual dengan cara dipikul atau didorong keliling kampung.

16. Pedagang "cimol" keliling: Cimol adalah sejenis makanan yang terbuat dari bahan dasar aci atau tepung singkong dan tepung terigu yang diberi ramuan bumbu penyedap, lalu dimasak dengan cara dikukus atau digoreng. Cara penyajiannya dengan ditusuk meng- gunakan semacam tusuk sate. Bentuknya bulat-bulat mirip kelereng. Mereka berjualan dengan cara berkeliling desa, dengan menggunakan sepeda atau dipikul.

17. Buruh tani: Pada dua dekade yang lalu, jenis pekerjaan ini sangat terkenal di kampung-kampung, misalnya dalam bentuk mencangkul, membersihkan lahan untuk penanaman padi, dan pekerjaan pengolahan lahan pertanian lainnya. Namun sekarang, meskipun masih ada, namun sudah kalah bersaing dengan pola buruhnya orang "kaya" yang menggunakan alat dan mesin traktor untuk mengolah sawah.

18. Buruh serabutan: Orang dengan pekerjaan "serba bisa" menurut ukuran kepentingan kehidupan penduduk desa. Jenis pekerjaan ini biasanya dilakukan oleh kaum lakilaki yang diberi upah secara harian atau hanya sekadar upah lelah karena jenis pekerjaan yang dilakukannya tidak sampai membutuhkan waktu satu hari penuh. Bentuk-bentuk pekerjaan ini antara lain adalah membetulkan selokan yang mampat, membetulkan genting yang melorot atau bocor, mem- bersihkan rumah, menggali sumur tetangga karena airnya surut di waktu kemarau, membetulkan dinding rumah yang sudah rusak dimakan aus dan rayap, dan jenis pekerjaan lain yang sifatnya tidak tetap. Penghasilan dari pekerjaan seperti ini biasanya jauh dari cukup untuk menopang kehidupan keluarganya.

19. Penarik becak: Meskipun jalan di desadesa dan kampung tempat penelitian ini berlangsung, banyak yang rusak, dan bahkan sangat sulit untuk dilalui becak, toh ada juga yang pekerjaannya sebagai penarik becak (penduduk setempat menyebutnya tukang becak). Banyaknya penghasilan penarik becak ini sangat tidak menentu, bahkan dalam sehari, terkadang tidak ada yang menggunakan jasanya, alias pulang tanpa membawa uang.

\section{Penggarap sawah atau ladang milik} orang lain: Istilah di pedesaan tempat penelitian ini dilakukan, dikenal dengan sebutan maro (bagi hasil, berbagi dua), mertelu (dibagi tiga), namun pada umumnya yang berlaku adalah maro atau nengah. Artinya, sang pemilik lahan atau sawah, tidak perlu mengeluarkan biaya apapun untuk menggarap sawahnya, sang penggaraplah yang bertanggung jawab terhadap pengolahan sawah dari mulai mempersiapkan awal menanam padi hingga memanen hasilnya. Hasil panen seluruhnya setelah dipotong untuk para penderep (pembawon), atau dalam istilah ekonomi dikenal dengan hasil bersih atau netto, dibagi dua, masingmasing pemilik sawah dan penggarapnya mendapatkan setengah atau $50 \%$.

\section{Beternak ayam kampung dan itik} secara tradisional: Hampir setiap rumah penduduk desa memiliki peliharaan ternak yang dikelola secara tradisional, terutama penduduk yang dikategorikan miskin. Uniknya, mereka tidak pernah memperhitungkan "untung-rugi" dari aktivitas pemeliharaan ternak ini. Misalnya 
ada sejumlah orang miskin yang memelihara ayam kampung, itik, dan entog, yang jika dikalkulasikan secara "analisis impas", tidak bisa mendatangkan hasil yang menguntungkan. Artinya, biaya pemeliharaan lebih besar dibandingkan dengan nilai jual ternak peliharaannya. Namun toh mereka tetap memeliharanya dengan alasan memanfaatkan sisa-sisa makanan sehari-hari. Bahkan, berdasarkan hasil observasi peneliti, mereka sering secara sengaja membuat nasi lebih banyak dengan tujuan untuk makanan ternak peliharaannya tadi. Dalam hati, peneliti berpikir, apa ini yang termasuk perilaku non eko- nomis.

22. Pemancing ikan di rawa-rawa: Sebenarnya hampir mirip dengan cara memancing ikan lainnya, yakni sama-sama menggunakan kail yang bermata pancing yang berfungsi sebagai penahan agar jika ikan sudah memakan umpan dan ditarik ke atas (permukaan air), ikan tidak bisa lepas karena akan tertahan oleh mata pancing yang dibuat tahanan terbalik. Yang membedakannya utamanya pada walesan (gagang pancing) yang digunakannya. Kalau gagang pancing ikan pada umumnya dibuat pendek namun diberi peralatan untuk melontar umpan supaya jauh ke tengah air, maka pada gagang pancing khusus ikan gabus, gagang pancingnya dibuat panjang, yakni dari bambu muluh (penduduk setempat menyebutnya pring wuluh). Biasanya meng- gunakan batang bambu khusus yang berukuran kecil namun cukup panjang, dengan ukuran bisa mencapai 5-10 meter, sehingga mampu menjangkau jarak yang cukup jauh dari diri si pemancing. Ikan jenis gabus ini biasanya akan memakan umpan berupa sejenis kodok sawah kecil (dikenal oleh penduduk setempat dengan sebutan bancet) yang sudah disiapkan oleh pemancing. Hasil dari usaha memancing ini tidak menentu, namun yang jelas, tidak bisa mencukupi kebutuhan hidup keluarga.

\section{Pengojek (jasa angkutan sepeda motor):}

Jenis profesi ini sudah sangat dikenal oleh masyarakat kita. Mencari pekerjaan dengan cara sebagai pengojek memang satu pilihan yang relatif khas, karena biasanya sang pengojek harus memiliki sepeda motor untuk digunakannya mengantar orang dari satu tempat ke tempat lainnya dengan membayar sewa atau jasa pengojekannya. Namun, tidak semua pengojek memiliki sepeda motor sendiri. Banyak di antara mereka yang menyewa dari orang lain. Jenis pengojek yang disebutkan terakhir inilah yang dimaksudkan dalam kategori orang miskin di pedesaan dalam penelitian ini. Ada dua jenis pengojek di sini, yakni pengojek jarak dekat dan pengojek jarak jauh. Yang pertama seperti yang biasa kita kenal selama ini, mereka hanya menarik penumpang di seputaran desa atau Kecamatan. Sedangkan yang jauh bisa sampai ratusan kilometer. Jarak terjauh yang pernah diantar menggunakan ojek ini antara lain adalah Majalengka, Tegal, Garut, Bandung, dan Kebumen.

\section{Pemijat (juru pijat atau tukang pijat):}

Jenis pekerjaan ini juga cukup dikenal oleh sebagian masyarakat kita, baik di desa maupun di kota. Mereka menjalankan profesinya dengan cara memijat orang lain dan mendapatkan upah darinya. Ada beberapa jenis pemijatan dalam hal ini, antara lain adalah: pijat pengobatan, pijat kesehatan, pijat dukun bayi (paraji), dan pijat membetulkan otot yang terkilir. Pekerjaan seperti 
ini juga bisa mendatangkan rizki yang tidak menentu, namun yang jelas, biasanya tidak bisa mencukupi kebutuhan keluarganya.

\section{Pencari keroto (sejenis serangga muda} untuk pakan burung): Keroto adalah nama yang diberikan oleh penduduk sekitar untuk telor dan anak-anak semut merah dan sejenis semut pohon lainnya yang sarangnya di hutan setempat, termasuk semut muda yang baru keluar dari telornya. Keroto ini merupakan bahan campuran pakan burung yang fungsinya sebagai protein dan makanan tambahan burung.

26. Dukun: Adalah satu sebutan untuk “orang pintar" yang dianggap memiliki pengetahuan supranatural. Orang yang menyandang profesi ini biasanya sering dikunjungi oleh sejumlah orang yang ingin berkonsultasi tentang apa saja yang diinginkannya. Mereka bisa datang untuk meminta diberikan petunjuk cara mencari kekayaan, berdagang, agar menang dalam pilihan pejabat publik, atau bahkan meminta pe- tunjuk cara mengobati suatu penyakit.

\section{Dukun pengobatan alternatif: Profesi} atau pekerjaan ini mirip dengan dukun seperti dimaksudkan pada nomor 26 di atas, namun jenis yang ini lebih khusus pada pekerjaan yang mengobati berbagai penyakit. Penduduk setempat menyebutnya dengan sebutan dukun. Dalam wacana yang muncul di lokasi se- tempat, dukun artinya "adu ngerukun", yang artinya seseorang yang bertindak untuk membuat "rukun" atau akur satu sama lain. Orang yang berprofesi sebagai dukun, biasanya dianggap memiliki kemampuan "linuwih" (lebih) dari orang lain sehingga dianggap bisa membantu menyembuhkan berma- cam penyakit. Hingga saat ini pekerjaan sebagai dukun masih ada di pedesaan tempat penelitian ini dilakukan.

\section{Penjaja barang kreditan milik orang}

lain: Orang dengan pekerjaan seperti ini secara rutin menjajakan barang-barang kebutuhan rumah tangga untuk dijual secara cicilan. Ada yang dicicil secara harian, mingguan, atau tiap hari "pasaran" atau hari pasar.

29. Pembuat "pipiti" (sejenis wadah bertutup dari anyaman bambu): Bentuknya semacam boks yang ada tutupnya dan berfungsi sebagai wadah makanan, bisa nasi dan laukpauknya, juga bisa untuk wadah bumbu masak dan di simpan di dapur. Ukurannya bermacammacam, mulai dari yang kecil, sedang, besar.

\section{Jasa penjualan bambu: Maksudnya} adalah orang yang pekerjaannya menjualkan bambu milik orang lain. Dia mengambil bambu sendiri, menjajakannya sendiri kepada orang yang membutuhkannya, baik di desa sendiri maupun di desa-desa tetangga. Salah satu contohnya adalah yang di kampung ini dikenal dengan Hamim. Penduduk setempat memanggilnya mang Hamim. Ia sudah dikenal oleh penduduk pedesaan setempat sebagai penjual bambu untuk keperluan dinding rumah (bilik), untuk pintu, untuk pagar rumah, usuk (kaso), reng, dan keperluan lain terkait rumah dan perabotannya. Profesi ini sudah ia lakukan secara turun temurun.

31. Pembuat bata dari tanah liat: Kegiatan ini lebih sebagai pekerjaan sambilan yang dilakukan oleh sejumlah penduduk desa tempat penelitian ini dilakukan. Di sela-sela waktunya 
yang ada, misalnya pagi hari sebelum mereka berangkat ke sawah atau tempat pekerjaan pokoknya, atau di sore hari setelah pulang dari kerja, mereka membuat bata dari tanah liat. Karena pekerjaan sambilan, maka jumlah bata yang dibuatnya tentunya tidak banyak. Setelah kering dijemur, bata tersebut dijual kepada orang yang membutuhkannya dalam keadaan mentah (belum dibakar) atau setelah matang (sudah dibakar).

32. Penyadap getah karet: Jenis pekerjaan ini membutuhkan keahlian yang khusus, atau setidaknya ada niat dan minat dari pekerja untuk melakukan pekerjaan ini. Umumnya, orang yang bekerja sebagai buruh sadap getah karet ini mendapatkan upah dari hasil sadapannya. Jika lahan atau kebun karetnya luas, maka sepanjang hari ia melakukan penyadapan dan mendapatkan penghasilan "lumayan" dari pekerjaannya ini. Pola hubungan kerjanya bisa berupa bagi hasil getah karet, atau diupah secara harian.

33. Pedagang "pecel" keliling: Jenis pekerjaan ini biasanya dilakukan oleh kaum ibu rumah tangga dengan maksud untuk membantu suami mencari nafkah guna menghidupi keluarganya, atau memang sudah dilakukannya dari dulu hingga sekarang karena sudah menjadi pekerjaan pilihannya. Nini Sage adalah salah seorang yang profesinya menjual pecel keliling kampung di Sidamulya, desa Sukamkti, Kecamatan Pamarican Kabupaten Ciamis. Hampir tiap hari ia menjajakan dagangan pecelnya ke rumah-rumah penduduk seputaran rumahnya. Peneliti pun pernah beberapa kali merasakan pecel Nini Sage ini ketika melakukan penelitian lapangan beberapa waktu yang lalu.
34. Warung nasi mangkal: Jenis usaha ini biasanya dilakukan oleh kaum ibu rumah tangga, baik sebagai pekerjaan pokoknya maupun hanya sifatnya sambilan. Pedagang warung nasi ini biasanya "mangkal" di lokasi tertentu yang diperhitungkan strategis karena banyak orang yang lewat melalui tempat atau jalan itu. Mereka menjual nasi rames dan lauk-pauknya secara sangat sederhana. Warung nasi ini juga melengkapi dirinya dengan menjual semacam makanan ringan tradisional seperti gehu (tauge dan tahu), pisang goreng, bala-bala, comro (oncom di jero, oncom di dalam), misro (amis di jero,manis di dalam), singkong goreng, dan makanan sejenisnya yang dimasak dengan cara digoreng atau dikukus.

35. Derep atau mbawon (mendapatkan upah dari membantu memanen padi milik tetangga): Ketika musim panen tiba, sejumlah penduduk desa, utamanya yang dikategorikan miskin, beramai-ramai melakukan pekerjaan yang dikenal oleh masyarakat setempat disebut derep atau mbawon, atau ani-ani (dari bahasa jawa), sedangkan dari bahasa Sunda, disebut dengan gacong. Pekerjaannya adalah mem- bantu memanen padi milik orang lain dengan mendapatkan upah dari hasi panenannya dengan cara dibagi antara yang menderep dan sang pemilik sawah dengan perbandingan yang umum dilakukan di wilayah setempat. Ada yang menggunakan perbandingan $5: 1,6: 1,7: 1$, atau 8:1, bagi pemilik sawah dengan pen- derepnya, bergantung hasil negosiasi antara para penderep dan pemilik sawah.

36. Penyeblok (nyeblok, ceblok): Adalah jenis pekerjaan seseorang yang secara "kontrak" 
atau perjanjian bersedia membersihkan (mengurus) sawah yang baru ditanami padi hingga masa panen. Orang tersebut tugasnya adalah membersihkan rumput liar yang tumbuh di selasela tananam padi (dikenal dengan sebutan matun), menyemprot tanaman padi dengan insektisida tertentu, dan memberi rabuk untuk menyuburkan tanaman padi. Ketika masa panen tiba, maka sang penyeblok tadi punya hak seper enam (1/6) bagian dari seluruh hasil panen. Orang lain tidak diperkenankan ikut derep atau mbawon di sawah yang diceblok ini. Jadi sifatnya adalah "monopoli" pekerjaan derep atau mbawon tadi. Penduduk setempat menyebutnya dengan mbawon manggon, artinya mbawon yang menetap di satu lokasi tertentu saja.

37. Pemelihara ternak milik orang lain: Sejumlah orang miskin di pedesaan ini, yakni Kecamatan Banjarsari dan Kecamatan Pamarican, Kabupaten Ciamis, melakukan pekerjaan dengan cara memelihara ternak, biasanya kambing, domba, atau sapi, dan mendapatkan upah setengah dari hasil peliharaan dimaksud, setelah dikurangi modal awalnya. Ada dua jenis pekerjaan seperti ini, yang pertama: membesarkan ternak, dan yang kedua: memelihara induk ternak dan berharap mendapatkan keuntungan dari ternak yang menurunkan anak ternak tadi. Contoh untuk yang pertama, membesarkan anak ternak, sang pemelihara akan mendapatkan hasil dari selisih nilai jual harga ternak setelah cukup umur. Keuntungan dari selisih nilai jual ternak dimaksud, nantinya dibagi dua dengan sang pemilik ternak (pemodal). Sedangkan untuk jenis pekerjaan yang kedua, sang pemelihara ternak akan mendapat setengah dari ternak yang dilahirkannya. Misalnya sang induk ternak melahirkan dua anak, maka sang pemelihara akan mendapatkan satu anak ternak dan sang pemilik modal mendapatkan satu anak ternak.

\section{Penjual "jasa” transaksi penjualan} (calo): Penduduk setempat menyebutnya dengan calo. Jenis pekerjaan seperti ini di kampung cukup dikenal, terutama untuk mediasi antara penjual tanah dan barang berharga lainnya dengan pembelinya. Yang paling dikenal adalah calo tanah, yang pekerjaannya mencari orang yang akan membeli dan atau menjual tanah. Dia akan mendapatkan penghasilan dari jasa transaksi penjualan atau pembelian tanah ini, misalnya $2 \%$, $3 \%, 5 \%$, atau bahkan ada yang sampai $20 \%$ dari nilai jual tanah, bergantung kepada "kelihaian" sang calo dimaksud. Jenis pekerjaan calo ini sebenarnya tidak hanya untuk masalah jual beli tanah, transaksi ekonomi pada aktivitas pekerjaan yang lain pun sekarang sudah ada calonya. Sebut saja antara lain seperti calo mobil, calo motor, calo penyewaan alat pesta, calo pe- nyewaan traktor pembajak sawah,

\section{Pembuat obat dari cacing tanah.}

Ada seorang penduduk desa di sini yang pekerjaan sehari-harinya mencari cacing tanah untuk kepentingan membuat obat penyakit tipes (typhus). Dia mencari cacing di pekarangan, di sawah, dan di tempat-tempat yang lembab dan basah, yang banyak cacingnya, untuk kemudian dibersihkan, lalu direbus hingga matang. Airnya dikemas dalam botol dan dijual kepada mereka yang mem- butuhkannya. Biasanya, menurut keyakinan penduduk desa ini, obat yang terbuat 
dari cacing tanah ini bermanfaat untuk mengobati penyakit tipes atau panas dalam.

40. Pembuat saleh (sale): Nama yang digunakan di wilayah ini namanya saleh, yakni sejenis manisan yang terbuat dari pisang matang yang diiris tipis-tipis lalu dijemur hingga kering atau sampai menyerupai keripik pisang. Saleh ini umumnya dibuat dari jenis pisang "siem", bukan jenis pisang lainnya. Setelah kering dijemur, lalu dikemas atau diikat dengan tali lalu dijual kepada bandarnya di Ciamis. Usaha jenis ini sekarang banyak dilakukan oleh penduduk kampung Pahauran Desa Sindangasih Kecamatan Banjarsari Ciamis. Namun seiring dengan perkembangan jenis usaha ini, orang-orang dari desa lainnya pun sudah mulai banyak yang mencoba membuat saleh ini, termasuk di Desa Sukamukti Kecamatan Pamarican Kabupaten Ciamis. Dengan adanya usaha ini, maka harga pisang siem di wilayah ini menjadi sangat tinggi, bahkan mengalahkan harga pisang ambon, pisang baja, dan raja, yang sebelumnya harganya lebih tinggi.

41. Pembuat keripik pisang: Pisang mentah, biasanya jenis nangka, diiris tipis-tipis, bisa menggunakan semacam alat iris, atau diiris menggunakan pisau dapur biasa yang tipis, kemudian diberi bumbu garam dan atau diberi tambahan bumbu penyedap lainnya, lantas digoreng hingga kering. Setelah dingin, pisang dikemas dalam plastik, direkat, dan dijual ke warung-warung sekitarnya.

42. Pembuat keripik singkong: Teknik pembuatannya mirip dengan cara membuat keripik pisang. Singkong dikuliti, lalu diiris tipis-tipis, lalu diberi bumbu penyedap seperlunya, dan digoreng hingga kering. Setelah dingin, baru dikemas dengan menggunakan plastik. Cara men- jualnya dititipkan ke warung- warung terdekat atau ke pasar.

43. Pembuat keripik gadung: Teknik pembuatannya cukup rumit dan memerlukan kesabaran. Gadung diiris tipis-tipis, lalu direndam dalam air garam yang sudah dicampur dengan lebu (abu, debu) hasil pembakaran dapur, dijemur hingga beberapa hari, biasanya dua hari.

Setelah itu dicuci, dilimbang (dibilas) beberapa kali untuk membuang racunnya. Setelah bersih, baru dikukus, kemudian dijemur hingga kering. Keripik gadung ini banyak dijual di pasarpasar tradisional atau dijual secara personal ke tetangga yang berminat.

44. Pembuat cetil: Cetil adalah sejenis jajanan pasar, terbuat dari tepung singkong (di desa ini dikenal dengan nama aci atau pati). Cara pembuatannya: Aci dimasukkan ke dalam air hangat, diaduk, dan digulung hingga menyerupai gulungan berbentuk silinder seukuran spidol white board marker, lalu dipotong-potong secara miring (diagonal atau menyerong), kemudian dikukus hingga matang. Cara penyajiannya dicampur dengan ampas kelapa dan sedikit gula putih. Anak-anak dan orang dewasa menyukai jajanan pasar ini.

45. Pengelola arisan: Seseorang yang mengadministrasikan kegiatan arisan secara proaktif. Artinya, para peserta arisan tidak perlu berkumpul di suatu tempat, mereka cukup diam di rumahnya masing-masing. Administrator lah yang secara aktif mengambil uang arisan sesuai dengan besaran yang disepakatinya. Di sini, yang dibuka adalah model arisan mingguan dengan setoran 
sebesar 10.000 rupiah; 20.000 rupiah, dan 30.000 rupiah. Jumlah anggota dibatasi sampai 20 orang, sehingga setiap minggu, setiap pemenang akan mendapatkan uang sejumlah 20 orang dikalikan dengan besarnya setoran. Pengelola arisan ini mengutip biaya dari setiap peserta, yakni 500 rupiah untuk yang besaran arisannya 10.000 rupiah, dan mengutip 1.000 rupiah untuk peserta yang besaran arisannya

20.000 ke atas. Pekerjaan seperti ini dilakukan oleh ibu rumah tangga sebagai pekerjaan "pokok"- nya.

46. Pedagang gorengan dititipkan ke warung: Biasanya dilakukan oleh kaum ibu, yang karena kebutuhan hidup, bekerja sebagai pembuat gorengan dari tepung beras yang diberi bumbu seperlunya. Setelah dikemas dalam plastik, lalu dititipkan ke warung tetangganya. Ada yang laku, ada juga yang gak laku. Tapi pekerjaan ini dilakukan dengan tujuan untuk menopang kehidupan keluarganya yang tergolong tidak татри (miskin).

47. Pedagang ikan sawah keliling: Kalau suaminya bekerja sebagai pencari ikan yang terdapat di rancah

atau rawa-rawa terdekat, maka hasil tangkapannya dijajakan oleh istrinya ke sejumlah tetangga di kampungnya. Ada yang dijajakan secara langsung dalam keadaan masih segar, atau ada juga yang sudah dimasak. Yang terakhir ini dilakukan untuk memenuhi kebutuhan makan siap saji kepada tetangga yang "biasa" membelinya. Para pedagang ini sudah tahu siapa yang biasa membeli dagangannya.

48. Pedagang jajan pasar keliling: Jajan pasar yang dimaksud adalah sejenis makanan ringan berupa cetil, intil, ciwel, getuk, lanting, cimpring, cantor, dan makanan sejenis yang bahannya dibuat dari bahan dasar singkong atau beras. Biasanya pekerjaan ini dilakukan oleh kaum perempuan. Mereka membuatnya sendiri dan menjajakannya sendiri ke rumah-rumah di lingkungan desa tempat tinggalnya.

49. Pedagang es keliling: Yang dimaksud adalah berdagang minuman yang dikemas dengan plastik, kecil- kecil seukuran lilin, diberi gula, dan dibekukan. Penduduk setempat menyebutnya dengan es lilin. Mereka berkeliling kampung menjajakan dagangannya itu. 50. Pedagang cilok dan cimol keliling: Biasanya dilakukan oleh kaum bapa (laki-laki yang sudah berkeluarga). Cilok (aci dicolok) atau cimol adalah sejenis makanan ringan yang terbuat dari aci singkong yang diberi adonan air secukupnya dan diberi bumbu penyedap, kemudian dibentuk bulat kecil-kecil seperti kelereng dan ditusuk menggunakan alat tusuk sate. Jenis makanan ini sangat digemari oleh anak-anak dan sebagian orang tua.

51. Pembuat sapu lidi: Biasanya dilakukan oleh kaum ibu atau kaum bapa yang sudah berusia lanjut. Sapu lidi ini dibuat dari lidi yang diambil dari janur pohon kelapa. Sapu lidi ini dijajakan keliling desa atau kampung.

52. Penggali sumur: Yang dimaksud adalah sumur gali, baik untuk keperluan rumah tangga ataupun untuk keperluan menyiran tanaman palawija di waktu musim kemarau. Pekerjaan ini biasanya dilakukan oleh orang yang masih kuat tenaganya.

53. Pencari bahan sayuran yang tumbuh liar di rancah dan rawa-rawa terdekat: Jenis 
pekerjaan ini biasanya dilakukan oleh kaum perempuan dewasa, yang tujuannya untuk membantu menutupi kebutuhan keluarga. Sayursayuran yang dimaksud di sini antara lain adalah sejenis kerema, gendot (genjer), eceng, bayam liar, dan jenis sayuran lainnya yang tumbuh secara liar. Sayuran ini dikemas untuk kemudian dijajakan ke pasar, ke warung, atau ke para tetangganya.

54. Tukang Gigi: Jenis pekerjaan sebagai tukang gigi atau dikenal juga sebagai tukang tambal gigi palsu adalah pekerjaan yang termasuk ke dalam keahlian khas, karena tidak bisa ditiru atau dikerjaan oleh orang lain secara mudah. Peralatan yang digunakan dalam pekerjaan ini cukup sederhana.

55. Pembuat kue donat untuk dijual di pasar: Kue donat dan kue sejenisnya adalah sejenis makanan ringan yang bahan dasarnya terigu yang diberi bumbu secukupnya kemudian digoreng. Kue-kue donat ini kemudian dijual di pasar terdekat. Hasilnya lumayan bisa untuk menyambung kebutuhan hidup sehari-hari bagi keluarganya.

Dari ke-55 jenis pekerjaan yang cukup bervariasi seperti digambarkan di atas, kemudian disederhanakan dengan menggunakan teknik kategorisasi yang didasarkan pada jenis-jenis pekerjaan serumpun. Pengelompokan ini meliputi jenis pekerjaan sebagai: buruh serabutan non pertanian, buruh tani serabutan, jasa caloan (mediator), jasa penarik becak dan ojek, pedagang sayuran dan makanan keliling, produksi pembuatan saleh pisang, produksi gula kelapa (penderes), pembuat dan penjual jajanan pasar, dan lainnya.
Tabel kategorisasi berikut menjelaskan jenis pekerjaan yang dilakukan orang miskin pedesaan dikaitkan dengan perilaku informasi yang melekat dengan jenis pekerjaan dimaksud, termasuk aspekaspek yang melingkupinya seperti sumber-sumber informasi dan saluran informasi yang menyertainya.

Tabel 1: Perilaku Informasi Terkait Jenis Pekerjaan Melekatnya

\begin{tabular}{|c|c|c|}
\hline No & $\begin{array}{c}\text { Perilaku } \\
\text { Informasi } \\
\text { terkait Jenis } \\
\text { Pekerjaan } \\
\text { Melekatnya }\end{array}$ & $\begin{array}{c}\text { Sumber } \\
\text { Informasi }\end{array}$ \\
\hline 1 & $\begin{array}{l}\text { Buruh serabutan non } \\
\text { pertanian }\end{array}$ & $\begin{array}{c}\text { Tetangga, } \\
\text { kerabat, sesama } \\
\text { buruh }\end{array}$ \\
\hline 2 & Buruh tani serabutan & $\begin{array}{c}\text { Tetangga, } \\
\text { kerabat, sesama } \\
\text { buruh }\end{array}$ \\
\hline 3 & $\begin{array}{l}\text { Jasa caloan } \\
\text { (mediator) }\end{array}$ & $\begin{array}{l}\text { Sesama calo, } \\
\text { tetangga dekat }\end{array}$ \\
\hline 4 & $\begin{array}{c}\text { Jasa penarik becak } \\
\text { dan ojek }\end{array}$ & $\begin{array}{c}\text { Sesama penarik } \\
\text { becak, orang } \\
\text { lewat }\end{array}$ \\
\hline 5 & $\begin{array}{c}\text { Penjual sayuran } \\
\text { keliling }\end{array}$ & $\begin{array}{c}\text { Tetangga dekat, } \\
\text { tetangga } \\
\text { selingkungan }\end{array}$ \\
\hline 6 & $\begin{array}{l}\text { Penjual makanan } \\
\text { keliling }\end{array}$ & $\begin{array}{c}\text { Tetangga dekat, } \\
\text { tetangga } \\
\text { selingkungan }\end{array}$ \\
\hline 7 & Pembuat saleh pisang & $\begin{array}{c}\text { Warung } \\
\text { terdekat, pasar } \\
\text { tradisional }\end{array}$ \\
\hline 8 & $\begin{array}{c}\text { Pembuat gula kelapa } \\
\text { (penderes) }\end{array}$ & $\begin{array}{c}\text { Warung } \\
\text { terdekat, pasar } \\
\text { tradisional, }\end{array}$ \\
\hline 9 & $\begin{array}{c}\text { Pembuat dan } \\
\text { penjual jajanan pasar }\end{array}$ & $\begin{array}{c}\text { Tetangga dekat, } \\
\text { tetangga } \\
\text { selingkungan }\end{array}$ \\
\hline 10 & $\begin{array}{c}\text { Penjual } \\
\text { lauk-pauk keliling }\end{array}$ & $\begin{array}{c}\text { Tetangga dekat, } \\
\text { tetangga } \\
\text { selingkungan }\end{array}$ \\
\hline
\end{tabular}

Sumber: Hasil Temuan Lapangan 
Tabel 1 di atas secara kategori menggambarkan kelompok jenis pekerjaan yang melekat dengan perilaku informasi penghidupan yang dilakukan oleh orang-orang miskin pedesaan. Mereka mencari dan menggunakan informasi terkait penghidupan atau pekerjaan kesehariannya. Dari 55 jenis pekerjaan yang dilakukan oleh orang miskin pedesaan, setelah dikelompokkan berdasarkan rumpun "rumpun" pekerjaan yang umumnya bersifat serabutan, menjadi sepuluh kelompok jenis pekerjaan. Ke-10 jenis informasi terkait pekerjaan terkategorisasi ini, kemudian dikaitkan dengan aspek sumber informasi sebagai bagian dari unsur perilaku informasi.

Tampak jelas bahwa, dari sepuluh jenis informasi terkait pekerjaan terkategorisasi, hampir seluruhnya ha- nya melibatkan sumber-sumber informasi yang berasal dari orang dengan lingkup yang amat terbatas. Hampir semua jenis pekerjaan yang ada hanya menggunakan informasi dan sumber- sumber informasi yang berasal dari lingkungan terdekat, seperti tetangga selingkungan, kerabat dekat, dan sesama pekerja sejenis.

Orang yang bekerja sebagai calo atau mediator, misalnya, tidak akan mencari dan menggunakan informasi yang berasal dari luar lingkup pekerjaannya. Hal ini juga berlaku bagi orang yang bekerja sebagai penjual sayuran keliling. Mereka tidak akan saling mencari dan menggunakan informasi di luar jenis pekerjaan yang dilakukannya selama ini. Mereka hanya berperilaku informasi secara amat terbatas. Artinya, mereka hanya mencari, menemukan, dan menggunakan informasi dan sumber-sumber informasi yang sesuai dengan lingkup jenis pekerjaannya.

Dalam konteks yang lebih luas, misalnya, informasi dan sumber-sumber informasi yang berasal dari unsur resmi atau formal, seperti dari sektor pemerintah, tidak pernah digunakan. Demikian juga dengan sumber dan saluran informasi yang berbasis media, baik cetak maupun elektronik, hampir tidak pernah digunakan oleh orang miskin pedesaan.

\section{SIMPULAN}

1. Beragam jenis dan sumber informasi yang dicari dan digunakan oleh orang miskin pedesaan, melekat dan mewujud dalam bentuk pekerjaan itu sendiri, yakni jenis pekerjaan serabutan di sektor pertanian tradisional.

2. Ruang lingkup dari jenis dan sumber informasi yang dicari dan digunakan oleh orang miskin pedesaan, amat terbatas, yakni seputar tetangga, kerabat dekat, dan sesama pekerjaan sejenis.

3. Informasi dan sumber informasi yang berasal dari unsur resmi atau formal, seperti dari sektor pemerintahan, hampir tidak pernah digunakan oleh orang miskin pedesaan. Demikian juga dengan sumber dan saluran informasi yang berbasis media, baik cetak maupun elektronik, hampir tidak pernah digunakan oleh orang miskin pedesaan.

\section{DAFTAR PUSTAKA}

Bank Dunia. (2006). Retrieved Agustus 2011, from Situs resmi Bank Dunia: ttp://go.worldbank.org 
Cresswell, J. W. (2008). Educational Research; Planning, Conducting And Evaluating Quantitative And Qualitative Research. New Jersey: Pearson Education.

Dunia, B. (2006). situs resmi bank dunia. Retrieved Agustus 2011, from Bank Dunia: http://go.worldbank.org

Rusastra, I. W., \& Napitupulu, T. A. (2010). Karakteristik Wilayah Dan Keluarga Miskin Di Pedesaan: Basis Perumusan Intervensi Kebijakan. Retrieved Agustus 2011, from Pusat Analisis Sosial Ekonomi dan Kebijakan Pertanian dan UNESCAPCAPSA: http://go.worldbank.org

Yusup, P. M. (2013). Makna Diri Penduduk Miskin Pedesaan. Indonesian Journal of DIALECTICS - IJAD, 85-89.

Yusup, P. M., Komariah, N., \& Rohanda. (2015). Mengungkap Pengalaman Keluarga Miskin Pedesaan di Jawa Barat dalam Menggunakan Informasi dan SumberSumber Informasi Kesehatan. Prosiding Simposium Nasional Komunikasi Kesehatan 2015 Fikom Unpad (p. 109). Sumedang: Fikom Unpad.

Yusup, P. M., Silvana, T. S., \& Subekti, P. (2013).

Memetakan Lingkup Informasi Penghidupan Orang Miskin Pedesaan. Jurnal Kajian Informasi dan Perpustakaan - JKIP, 21-28. 